\title{
Management of erosion hazard with the agro technology in watershed aie limau kambiang on the upper watershed tarusan
}

\author{
Aprisal $^{1}$, Bambang Istijono ${ }^{2, *}$, and Reski Permata Sari $^{1}$ \\ ${ }^{1}$ Faculty of Agriculture, Andalas University \\ ${ }^{2}$ Faculty of Engineering, Andalas University
}

\begin{abstract}
One of the hazards of the erosion is soil infiltration capacity is decreased in the place of occurrence of erosion and increasing the volume of surface flow. It will also lead to the occurrence of the superficiality of the river due to the deposition of materials of soil erosion. These hazards need alternative agrotechnology which could reduce the rate of soil erosion. This research is to know the hazard of soil erosion in the upper watershed of the Aie Limau Kambiang and find out the alternative agrotechnology for reducing the soil erosion. This research was conducted. Soil samples collected was taken in purposive random sampling based on a unit of land. The data were analyzed using the universal soil loss equation. The research results of the largest erosion threat come from the land use of traditional gardens and plant density is low. The highest erosion 151,012.00 ton/ha/year was founded on the plantation blended that have a steep slope over $35 \%$ LS value of 9.5 . The better of agrotechnology with increasing plant density, that could reduce erosion to 503.40 ton/ha/year. This means that the hazard of soil erosion could be controlled with land management and selected of the better agrotechnology.
\end{abstract}

\section{Introduction}

Upstream river basin area based on its function is a conservation area or water catchment area. This is because the upstream area has a steeper slope. However, due to the high pressure of the population, this area is targeted as a farming area, such as gardens that generally do not pay attention to soil conservation methods so that the surface flow and erosion are high [1]. Erosion occurs due to the process of destruction of soil aggregates by the kinetic energy of rainfall. The soil will experience fractionation into clay, dust and sand and soil organic matter. Then the ground was washed away by the strength of the surface flow to the lower slope and kept partway into the stream and deposited on the quiet and flat part [2].

The eruption is actually a natural process that is easily recognizable, but in most places, it is exacerbated by human activities in poor land use, deforestation, mining, plantation, and cultivation. Utilization of soil to produce agricultural crops typically has much greater erosion of soil with forest vegetation. The conversion of forests into agricultural fields increases erosion because the strong root structure of forest plants binds the soil is replaced by weaker crop root structures. To suppress small erosion or equal to erosion which permits should find alternative agrotechnology appropriate to this area such as contour cropping system integrated with gulud terrace [3].

The Tarusan watershed is one of the priority watersheds according to BPDAS Agam Kuantan Office.
The Tarusan watershed is one of the watersheds located in Koto XI Tarusan Subdistrict of Pesisir Selatan Regency. The Tarusan watershed covers 51,740 ha with a stream length of $52.47 \mathrm{Km}$ Batang Tarusan stretches in Pesisir Selatan Regency in West Sumatera Province. This river comes in the vicinity of the hill line between Solok District and Pesisir Selatan Regency. The area of the Batang Tarusan flow covers an area of $508.34 \mathrm{~km} 2$, which empties into the Indian Ocean with an average discharge of $1.826 \mathrm{~m} 3$ / sec. [4].

The land use is generally dominated by Tarusan river basin $(2,038 \mathrm{Ha})$, gambier $(9,064 \mathrm{Ha})$, brown $(1,096 \mathrm{Ha})$, protected forest $(13,187 \mathrm{Ha})$. Land used by the community in Tarusan watershed is a land that has hilly topography or slope and steep. One of the subwatersheds of this Tarusan watershed is the attention of Aie Batu Kambiang sub-watershed because in this subwatershed has also a lot of lands including steep is utilized by the community. This will have an impact on rising surface flows and erosion as well as silt of streams in the lower reaches of the Tarusan watershed so that rapid river floods occur. The results of the study [5] show that the surface runoff, erosion and sedimentation found in the Masang Besar sub-basin in Agam district are found in the use of cultivated lands or gardens especially those with steeper slopes.

To predict erosion and small erosion planning, or equal to the permissible erosion of the universal soil loss equation (USLE) models; the most commonly used method. The USLE method can be used to predict the magnitude of erosion for different land-use conditions

Corresponding author: bistijono@eng.unand.ac.id 
and different climatic conditions. USLE allows planners to predict the average erosion rate of a certain land on a slope with a specific rain pattern for each soil type and land management (land conservation). USLE is designed to predict long-term erosion of sheet erosion and flow erosion under certain conditions. The equation can also predict erosion on non-agricultural lands, but not to predict sediment [6].

Calculation of erosion damage is highly influenced by rainfall factor, slope length, slope, soil, and land cover and management action. The main factors causing erosion are rainfall and the presence of surface flows [7]. The research objectives predict soil erosion in the Aie Limau Kambiang sub-basin on the Tarusan basin and look for appropriate agrotechnology to suppress it as small or equal to the permissible erosion.

\section{Research methodology}

\subsection{Research location}

This research was conducted in October 2017 - January 2018 on the various land area of land in sub-basin Aie Limau Kambiang, Pesisir Selatan, West Sumatra province, Indonesia. The soil analysis will be carried out at Soil Physics Laboratory, University of Andalas, Padang.

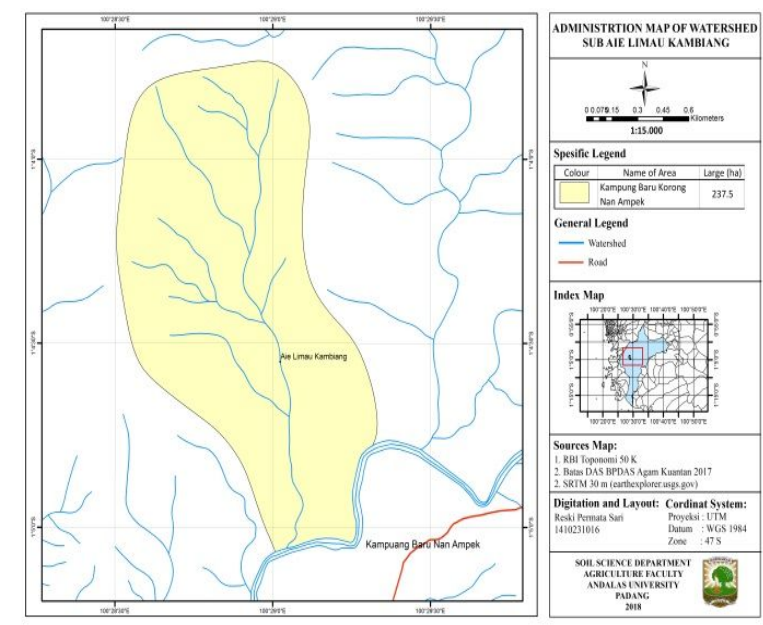

Fig. 1 Map of Aie Batu Kambiang Sub-watershed Administration on the Tarusan Watershed.

\subsection{Tools and materials}

The tools used in research are GPS (Global Positioning System), Belgian drill, command knife, ring sample. Peroxide acid materials, aquades, Nahexametaphosphate, hydrochloric acid and working maps of Batu Kambiang sub-basin.

\subsection{Research methodology}

Field research was conducted by survey method. The research was conducted in several stages (1) preparation,
(2) main survey and sampling (3) soil analysis in laboratory (4) data processing.

\subsubsection{Rainfall data}

Rainfall data were obtained from the Meteorology Climatology and Geophysics Agency (BMKG) Sicincin from 2011-2016. Rainfall data is processed by using the Bolds formula to obtain rain erosivitas. The formula put forward by Bolds (1978) cit Arsyad (2010) as follows:

$E I 30=6,119(R A I N) 1,21(D A Y S)-0,47(M A X P) 0,53$

EI30 is the monthly rainfall erosion index, RAIN is the monthly average rainfall in centimeters, DAYS is the number of days of average rainfall per month, and MAXP is the maximum rainfall for 24 hours in a cyclical month.

\subsubsection{Determining the soil erodibility value}

Soil erodibility value can be calculated by the following formula:

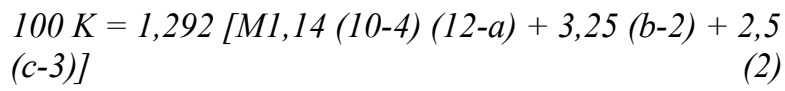

Annotation:

$K=$ Soil erodibility factor

$M=(\%$ dust $+\%$ very fine sand $) \times(100-\%$ clay $) 10$

$a=$ Percentage of organic matter

$b=$ Class of soil structure

$c=$ Soil permeability grade

\subsubsection{Mapping}

Topographic maps, slopes, land use, obtained from SRTM (Shuttle Radar Topography Mission) data analysis into DEM (Digital Elevation Model) data in Global Mapper 16 and contour data using Arc GIS 10.2.1 software using counters in the arc toolbox.

\subsubsection{Determining the slope}

The estimated slope factor value is based on the slope percentage. The magnitude of the slope is predicted with a slope class map.

Table 1. How to grade gradients to determine the value of (LS).

\begin{tabular}{|c|c|c|}
\hline Slope Class & Slope (\%) & LS \\
\hline A & $0-5$ & 0.25 \\
\hline B & $5-15$ & 1.20 \\
\hline C & $15-35$ & 4.25 \\
\hline D & $35-50$ & 9.50 \\
\hline E & $>50$ & 12.00 \\
\hline
\end{tabular}

Source: Standard Operation Procedure RTL-RLKT Jakarta (1986) 


\subsection{Main survey}

In the main survey, soil sampling was done according to the point specified on the map. The samples taken were determined by purposive random sampling, ie. the samples were taken based on the land units in the Aie Batu Kambiang of Tarusan Sub-watershed. Samples taken are disturbed soil samples and soil samples intact. Disturbed soil samples are captured using a Belgian drill or hoe. Samples were taken 3 replicates on each unit of land. Whole ground samples were taken using a sample ring, samples were taken on each unit of land.

\subsection{Soil analysis in the laboratory}

Samples taken in the main survey were analyzed in the laboratory. Analysis of disturbed soil samples to be performed in the laboratory is the determination of texture by the method of pipettes and sieves, Groundwater Level Determination method Gravimetry, and C-organic methods Wakley and Black. While for the analysis of intact soil sample is Determination Permeability De Boodt method.

\subsection{Calculating soil erosion value}

To predict the magnitude of soil erosion in USLE formulas from Wischmeier and Smith (1978). The USLE formulation is as follows.

$A=R \times K \times L \times S \times C \times P$

Annotation :

$A=$ The rate of soil erosion (ton/ha/year)

$R=$ Rainfall erosivity index

$K=$ Index of soil erodibility

$L=$ Index of slope length

$S=$ slope inclination index

$C=$ Index of vegetation cover

$\mathrm{P}=$ Index of land treatment or action of soil conservation

To determine the values of $\mathrm{C}$ and $\mathrm{P}$ are based on Table 2.

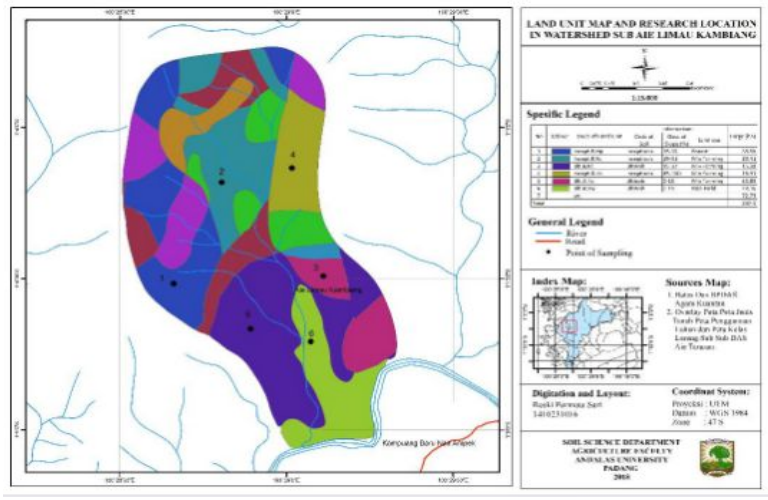

Fig. 2 The use of a sub-watershed area of Batu Kambiang in Tarusan watershed
Table 2. The value of C X P on some land use

\begin{tabular}{|c|c|c|}
\hline No. & Land Use Type & $\mathrm{CP}$ \\
\hline 1. & The undisturbed forest & 0.01 \\
\hline 2. & Forest without plants & 0.01 \\
\hline 3. & Forests with no plants and litter & 0.50 \\
\hline 4. & Shrubs/groves partially overgrown with & 0.10 \\
\hline 5. & grass & 0.01 \\
\hline 6. & The undisturbed underbrush & 0.07 \\
\hline 7. & A mixed garden & 0.01 \\
\hline 8. & $\begin{array}{l}\text { Hardwood plantations with partial ground } \\
\text { cover }\end{array}$ & 0.20 \\
\hline 9. & The yard & \\
\hline & Plantation of hard plants with some plants & 0.07 \\
\hline $\begin{array}{l}10 . \\
11 .\end{array}$ & $\begin{array}{l}\text { ground cover } \\
\text { Grass cover grass }\end{array}$ & $\begin{array}{l}0.02 \\
0.06\end{array}$ \\
\hline 12. & Reed grass is burned every year & 0.65 \\
\hline 13. & Lemongrass & 0.01 \\
\hline 14. & Grass ground cover well & 0.63 \\
\hline 15. & Plant tubers & 0.36 \\
\hline 16. & Plant moor beans & \\
\hline & General agriculture with: & 0.14 \\
\hline & - use mulch & 0.04 \\
\hline & - patio benches & 0.14 \\
\hline 17. & - bunds & 0.258 \\
\hline 18. & Sorghum Crotalaria strip & 0.345 \\
\hline 19. & Sorghum strip grass & 0.438 \\
\hline 20. & Sorghum strip beans & 0.380 \\
\hline 21. & Peanut strip Brachiaria & 0.205 \\
\hline 22. & Cowpea strip Brachiaria & 0.200 \\
\hline 23. & Single Crotalaria strips & 0.880 \\
\hline 24. & Upland rice stripe grass & 0.890 \\
\hline 25. & Patio bench + sorghum & 0.890 \\
\hline 26. & Patio bench + corn & 0.012 \\
\hline 27. & Patio bench + peanuts & 0.070 \\
\hline 28. & Patio bench + corn & 0.025 \\
\hline 29. & Patio bench + peanuts & 0.050 \\
\hline 30 . & Patio bench + peanut + corn & 0.060 \\
\hline 31. & Patio bench + corn + manure & 0.040 \\
\hline 32. & Patio bench + maize + peanut + manure & 0.008 \\
\hline 33. & Patio bench + upland rice & 0.020 \\
\hline 34. & Patio bench + beans + bitumen & 0.035 \\
\hline 35 . & Patio bench terrace + beans & 0.003 \\
\hline 36. & Teracce bunds + beans & 0.020 \\
\hline 37. & Teracce bunds + singgle beans & 0.008 \\
\hline 38. & Teracce bunds + corn & 0.114 \\
\hline & Teracce width + beans & \\
\hline
\end{tabular}

Source : Weischmeier, 1980

According to [8] proposes an acceptable rate of erosion calculation based on the depth of the soil equivalent and the duration of preservation of expected soil resources by equation:

$$
T=K E * F K / U G T
$$

Q : Erosion allowed (ton / ha / year)

KE: Effective depth of soil ( $\mathrm{mm}$ )

FK: Depth factor of the land sub-order

UGT: Ground age (for preservation use 100 years) 


\section{Results and discussion}

\subsection{Rain erosivity}

Based on the analysis of rainfall data with Bolds 1978 formula, rainfall erosivity value is found in Aie Batu Kambiang sub-waters as in Table 2. The average erosivity during the last six years is 246,112. This erosiveness demonstrates the ability of the destructive force of rain to crush aggregate soil into clay fraction, dust and sand. This is closely related to the maximum amount of rainfall, the amount of rain that occurs in each rainy month. According to [9] states that the most important character of the rain on the occurrence of soil erosion is precipitation, intensity, and distribution. The important properties of this rain together will determine the ability of rain to crush the grains of the soil as well as the amount and velocity of runoff. According to [10] states that the energy from falling rain falling leads to the release of soil particles from the soil structure. The higher the intensity of rainfall will produce higher the more soil particles that are detached from the clods of soil. This loose soil will be thrown along with a splash of water.

\subsection{Soil erodibility}

Soil erodibility is the sensitivity of the soil to the easiness of the soil eroded by rain. To determine the sensitivity of this soil first in the analysis of soil physical properties such as texture, organic matter, permeability, and soil structure. Each unit of land has different soil erodibility values and this is closely related to differences from organic materials, texture, and soil structure due to different land uses. According to [2] explains that in the event of erosion, the subtle fraction of the soil will be raised first and more of the coarse fraction. This is related to the carrying capacity of the surface flow to different grains of soil.

\subsection{Soil erosion}

Based on the calculation of erosion prediction in sub-Aie Batu Kambiang Tarusan, the largest erosion was found in mixed garden land use (Incept D Kc). The cause of high erosion in this unit of land is caused by the steeper slope of the land, ie $30-45 \%$ with the value of LS 9.5. Thus the flow of the surface flows faster and the energy is greater to carry the ground grains. According to [2] also states that the steeper the slope increases the greater the erosion occurs. According to [11] states, some of the physical characteristics that greatly affect the erosion process in the watershed are the slope of the land, soil type, and land cover. According to [12] steep slopes (with slopes between 15-40\%) more easily eroded. If coffee plants are young and still slightly canopy, erosion may exceed tolerable limits.

Besides, the use of land with a mixture of people's garden with low intensity. This causes the rainfall granules to easily enter through the canopy escaping to the soil surface and destroying the aggregate of the soil. Based on the results of the research [5] in the Masang Basin sub-districts indicate that the land used for mooring and mixed gardens having rare canopy cover has an actual erosion higher than erosion tolerance.

\subsection{Allowable erosion}

The amount of soil erosion tolerated in the two land orders in the subwatershed is ultisol and inceptisol (Table III). According to [2] The value of erosion tolerance is sought by the formula.

Table 3. The value of erosion that can be tolerated in two types of soil in Aie Batu Kambieng Tarusan Subwatershed.

\begin{tabular}{|c|c|c|}
\hline No & Soil Order & $\begin{array}{c}\text { Allowable Erosion } \\
\text { t/ha/year }\end{array}$ \\
\hline 1 & Ultisol & 150 \\
\hline 2 & Inceptisol & 112 \\
\hline
\end{tabular}

\subsection{Agrotechnology to suppress erosion rate}

To reduce the high rate of erosion, a more appropriate agrotechnology option is needed, ie plant canopy can protect the soil surface. Rarely, mixed community gardens need to be increased intensity with productive crops and can increase farmers' acceptance. Productive plants and have aspects of conservation are durian, jengkol, petai, jackfruit and mangosteen. Thus soil erosion can be suppressed equally with permissible erosion.

To suppress the rate of erosion equal to the tolerable erosion, the multiplication between plant coefficients (C) and conservation measures $(\mathrm{P})$ or $\mathrm{CP}$ must have values ranging from 0.001 to 0.0058 . Based on the calculation of the $\mathrm{CP}$ value of conservation management result, erosion value in the mixed garden (incept $\mathrm{D} \mathrm{Kc}$ ) can be reduced to 503,4 ton / h / year. Similarly, other land units have lower erosion values.

\section{Conclusions}

Based on the results of research on the sub-waters Aie Batu Kambiang, it can be concluded that:

1. Highest erosion in sub-watershed of Batu Kambiang was 151,012 ton/ ha/year in Incept D Kc land unit or in the mixed garden with a steep slope

2. The erosion can be reduced to 503,40 ton/ ha/year by using agrotechnology.

To the Head of the Soil Department, I thank you for the facilities provided for the analysis of soil in the laboratory. This research is funded by Andalas University under Research Grant No 43/UN.16.17/ PP.RGB /LPPM/ 2018 dated April 23, 2018. 
Table 4. Erosivity of rainfall from 2011 to 2016 in Aie Batu Kambiang of Tarusan Sub-watershed

\begin{tabular}{|l|l|l|l|l|l|l|c|}
\hline \multicolumn{1}{|c|}{ Month } & \multicolumn{1}{|c|}{2011} & \multicolumn{1}{c|}{2012} & 2013 & 2014 & 2015 & 2016 & Average \\
\hline January & 23,509 & 4,081 & 17,628 & 4,081 & 10,119 & 17,844 & 12,877 \\
\hline February & 8,668 & 4,725 & 21,643 & 8,569 & 16,706 & 8,368 & 11,447 \\
\hline March & 8,182 & 10,516 & 4,958 & 18,891 & 34,016 & 19,656 & 16,037 \\
\hline April & 37,149 & 2,234 & 26,440 & 15,890 & 22,417 & 37,775 & 23,651 \\
\hline May & 5,740 & 18,715 & 5,275 & 11,823 & 26,390 & 32,992 & 16,823 \\
\hline June & 39,337 & 4,168 & 10,164 & 27,083 & 28,964 & 26,436 & 22,692 \\
\hline July & 19,260 & 4,484 & 13,962 & 9,486 & 6,001 & 23,610 & 12,801 \\
\hline August & 24,032 & 20,757 & 29,989 & 23,447 & 20,016 & 8,278 & 21,087 \\
\hline September & 9,498 & 3,336 & 10,918 & 9,479 & 15,282 & 15,067 & 10,597 \\
\hline October & 21,815 & 31,942 & 8,041 & 29,949 & 9,849 & 55,747 & 26,224 \\
\hline November & 63,936 & 12,827 & 29,778 & 47,896 & 30,067 & 20,214 & 34,120 \\
\hline December & 20,373 & 76,890 & 90,651 & 14,161 & 13,288 & 16,828 & 38,699 \\
\hline & & & & & & $R$ & 246,112 \\
\hline
\end{tabular}

Table 5. Physical Characteristics of the Soil in the Sub-watershed Aie Batu Kambiang of Tarusan

\begin{tabular}{|c|l|l|c|c|c|c|c|l||}
\hline No & Code & Land Unit & $\%$ Sand & $\%$ Silt & \% Clay & BV $\left(\mathrm{g} / \mathrm{cm}^{\mathrm{j}}\right)$ & Hydroulic Conductivity (cm/hour) & Structure \\
\hline 1 & SPL1 & Incept.B.Hp & 1 & 84 & 15 & 0.9 & 135.7 & Granular Crude \\
\hline 2 & SPL2 & Incept.B.Kc & 34 & 44 & 22 & 1.04 & 11.5 & Angular Blocky \\
\hline 3 & SPL3 & Ult.B.Kc & 6 & 29 & 65 & 0.79 & 56.4 & Angular Blocky \\
\hline 4 & SPL9 & Incept.D.Kc & 8 & 33 & 59 & 1.01 & 54.8 & Angular Blocky \\
\hline 5 & SPL 12 & Ult.A.Kc & 4 & 39 & 57 & 0.89 & 7.9 & Angular Blocky \\
\hline 6 & SPL 14 & Ult.A.Sw & 9 & 6 & 87 & 0.79 & 22 & Angular Blocky \\
\hline \hline
\end{tabular}

Table 6. Land Sensitivity Value at Aie Batu Kambiang in Tarusan Sub-watershed

\begin{tabular}{|c|c|c|c|c|c|c|c|c|}
\hline \% Very fine sand & Silt & Clay & $\mathrm{M}$ & $\mathrm{M}(1.14)$ & $\mathrm{a}$ & $\mathrm{b}$ & $\mathrm{c}$ & Erodibility \\
\hline 0.07 & 84 & 15 & 7146.1 & 24753.7 & 7.49 & 3 & 6 & 0.28 \\
\hline 0.69 & 44 & 22 & 3486.1 & 10921.2 & 4.74 & 4 & 4 & 0.22 \\
\hline 0.05 & 29 & 65 & 1016.8 & 2680.6 & 7.95 & 4 & 6 & 0.19 \\
\hline 0.1 & 33 & 59 & 1357.1 & 3725.4 & 4.85 & 4 & 6 & 0.22 \\
\hline 0.04 & 41 & 57 & 1764.9 & 1764.9 & 6.9 & 4 & 4 & 0.15 \\
\hline 0.05 & 6 & 87 & 78.7 & 78.7 & 3.54 & 4 & 3 & 0.09 \\
\hline
\end{tabular}

Table 7. The slope on some land units and the value of LS at Air Batu Kambiang in Tarusan sub-watershed

\begin{tabular}{|c|c|c|c|c|}
\hline No & SPL Code & Land Unit & $\begin{array}{c}\text { Slope } \\
(\%)\end{array}$ & LS Value \\
\hline 1 & SPL 1 & Incept.B.Hp & $15-30$ & 1.2 \\
\hline 2 & SPL 2 & Incept.B.Kc & $15-30$ & 1.2 \\
\hline 3 & SPL 3 & Ult.B.Kc & $15-30$ & 1.2 \\
\hline 4 & SPL9 & Incept.D.Kc & $30-45$ & 9,50 \\
\hline 5 & SPL 12 & Ult.A.Kc & $0-15$ & 0.25 \\
\hline 6 & SPL 14 & Ult.A.Sw & $0-15$ & 0.25 \\
\hline
\end{tabular}


Table 8. The value of erosion factor and soil erosion in Aie Batu Kambing of Tarusan sub-watershed

\begin{tabular}{|l|c|l|c|c|c|c|c|c|c|}
\hline No & $\begin{array}{c}\text { SPL } \\
\text { Code }\end{array}$ & Land Unit & $\begin{array}{c}\text { Erosivity } \\
\mathrm{R} \\
(\mathrm{KJ} / \mathrm{h} / \text { /year })\end{array}$ & $\begin{array}{c}\text { Erodibility } \\
\mathrm{K}\end{array}$ & $\begin{array}{c}\text { Slope } \\
(\%)\end{array}$ & LS & C & P & $\begin{array}{c}\text { A } \\
\text { t/ha/year }\end{array}$ \\
\hline 1 & SPL 1 & Incept.B.Hp & 246112.0 & 0.3 & $15-30$ & 1,2 & 0,005 & 1 & 83,6 \\
\hline 2 & SPL 2 & Incept.B.Kc & 246112.0 & 0.2 & $15-30$ & 1,2 & 0,3 & 1 & $19.378,7$ \\
\hline 3 & SPL 3 & Ult.B.Kc & 246112.0 & 0.2 & $15-30$ & 1,2 & 0,3 & 1 & $17.268,8$ \\
\hline 4 & SPL 9 & Incept.D.Kc & 246112.0 & 0.2 & $30-45$ & 9,50 & 0,3 & 1 & $151.012,0$ \\
\hline 5 & SPL 12 & Ult.A.Kc & 246112.0 & 0.1 & $0-15$ & 0,25 & 0,3 & 1 & $2.757,7$ \\
\hline 6 & SPL 14 & Ult.A.Sw & 246112.0 & 0.1 & $0-15$ & 0,25 & 0,05 & 0,04 & 10,5 \\
\hline
\end{tabular}

\section{References}

1. Asdak, C. 1995. Hydrology and watershed management. First Printing. Gadjah Mada University Press, Bulaksumur, Yogyakarta

2. Arsyad, S. 2010. Conservation of land and water. IPB. Dargama, Bogor

3. Soemarno. 2006. The vegetation for soil and water conservation. Environmental Conservation.

4. The National Board of Statistic. 2017. Pesisir Selatan regency in figures. Catalog Number: 1102001.1302 Publication Number: 13020.1702

5. Aprisal, Bujang Rusman, and Darmawan. 2017. The optimization of land use in the Batang Masang watershed to reduce the rate of surface flow, erosion, and sediment. (Case studies, Batang Masang watershed in Agam district, West Sumatra). Proceeding National Conference, University of Riau.

6. Suripin. 2002. Conservation of soil and water resources. Andi Publisher. Yogyakarta. 208 it

7. Wischmeier, w. h., and d. d. Smith. 1978. Predicting rain shower erosion losses: A guide to conservation planning. Sci. and Educ. Adm. USDA in cooperation with Purdue Agric. Exp. STA

8. Hammer, w. i., 1980. Soil Conservation Consultant Report Center for Soil Research, Bogor, Indonesia. Technical Note

9. Utomo, W. H., 1989. Soil conservation in Indonesia. A Recording and analysis of an Eagle Press, Jakarta

10. Morgan, RPC, 1988. Erosion and soil conservation. John Wiley Sons \&, Inc., New York

11. Ram Gupta S, 1989, Hydrology and hydraulic systems, Prentice Hall, New Jersey

12. Agus, F. Ngaloken Gintings, and Meine van Noordwijk. 2002. The choice of technology. 